\title{
A demand and capacity analysis on bus semirapid transit network (Case: Jabodetabek public transport network)
}

\author{
Alvinsyah $^{1, *}$, and Edi $\operatorname{Hadian}^{1}$ \\ ${ }^{1}$ University of Indonesia, Civil Engineering Department, Jakarta, Indonesia
}

\begin{abstract}
The objective of this research is to estimate the potential demand and capacity for Jabodetabek Bus Semi rapid Transit (BST). A transport model based on four step modeling is utilized to analyze the demand at network level. The model is developed from previous works and adjusted through a calibration and validation procedure with data from the field. The base year O-D matrix is calibrated by trip length frequency distribution through a matrix balancing process. While the passenger flow is validated through transit assignment procedure with data on the existing bus routes. Based on the assumptions made and different operational characteristics and fare system scenarios, a simulation through the developed model on the proposed BST is conducted. From the analysis, the total boarding, the passenger flow on peak hour for each BST corridor are obtained. Based on the average and maximum passenger flow, the required capacity for each corridor is determined.
\end{abstract}

\section{Introduction}

City of Jakarta and its surrounding (bodetabek) area, consists of DKI Jakarta (Special Capital District of Jakarta) and its eight surrounding municipalities, is known as a city of chronic and severe congestion with increase of motorized vehicles. Therefore to tackle this chronic problem, a new agency called Badan Pengelola Transportasi Jabodetabek (BPTJ), responsible for all transportation issues in Jabodetabek (Greater Jakarta) area is established. One of its main responsibility is to prepare and implement Transport Master Plan for Jabodetabek Area (RITJ). Referring to the draft of RITJ [1] seems that the most ambitious and potential program that should be implemented in a very short period is its High Capacity Bus/HCB (i.e. Bus Rapid Transit/BRT) network plan as shown in Figure A-1 in the appendix. While, the whole Mass Transit Network are shown in Figure A-2 and Figure A-3 respectively in the appendix. Having reviewed the RITJ and the existing TransJakarta Busway system, and also referring to Vuchic [2], this kind of HCB system can be categorized as Bus Semirapid Transit (BST).

Assumming that the definition of BRT [3, 4] is held, and taking into account the existing physical condition for its proposed network, it seems that BPTJ needs a special treatment and very extra effort to accomplished this Plan. Since passenger demand or

* Corresponding author: alvinsyah2004@gmail.com 
ridership plays a dominant role in urban mass transit system, often used as a basis reference to determine the capacity of mass transit [5-7], it is crucial to conduct a demand assessment to the proposed plan either at network level or at route level. Accordingly, the objective of this research is to conduct a demand analysis and to determine the design capacity on each proposed BST service line.

The following sections describe the research framework, assumptions and scenarios, simulation and analysis, and finally the research conclusion.

\section{Research framework}

This research is commenced by reviewing some previous works [1, 8-12] to prepare a transport model. In general, the preparation of public transport passenger demand forecasting model is based on network development on supply side and the projected socioeconomic framework on demand side which involves network scenario development for mass transit system. By adapting the four step model from previous works [1, 8, 10, 13-16] a calibration and validation procedure, to update the model, are then conducted. The model calibration procedure is explained in a more detail in Hadian and Alvinsyah [17]. Once the updated model, commonly called as base year model, is set, then it is utilized to estimate future motorised person trips. Taking the actual mode share composition [11], this total motorised person trip is split into trips with private vehicle (i.e. car and motorcyle) and trips with public transport.

Since current public transport service is dominated by bus system and the mass transit plan in RITJ is mostly road-based system, it is necessary to conduct road network performance analysis repesented in speed on each link in the network. The estimated speed is derived from the highway equilibrium assignment simulation. A more detail explanation on this assignment procedure can be found in Alvinsyah dan Hadian [8]. This estimated speed will be used as a basis (i.e. operational speed) in estimating the potential public transport demand, especially the roadbase mass transit demand.

Having obtained the total public transport trip, then, this trip is assigned to the existing and the planned public transport network through a transit assignment procedure. In the validation process, the person trip from the O-D matrix is assigned to the transit network and adjustment to all parameter values in the generalised cost are made until the passenger flow from the assignment process is conformed with that of from field data.

In transit assignment model, the monetary cost, which is fare applied to each particular line services is converted to 'time' and is weight-combined with total travel time which consists of in-vehicle, waiting at stops, access and egress time components in the specific form called 'generalized cost' function. This function is expresed in the following [18];

$$
C_{i j}=a_{1} t_{i j}^{W}+a_{2} t_{i j}^{W}+a_{a} t_{i j}^{t}+a_{4} t_{i j}^{n}+a_{1} \delta^{n}+a_{5} F_{i j}
$$

where,

$t_{i j}^{v}=$ In vehicle time from $i$ to $j$

$t_{i j}^{w}=$ Walking time from station or to station

$t_{i j}^{t}=$ Waiting time at the station

$t_{i j}^{n}=$ Transfer Time at station

$\delta^{n}=$ Penalty for transfer

$F_{i j}=$ Fare from $i$ to $j$ 
$a_{1}$ to $a_{5}=$ Coefficients.

The macro planning software called EMME is used to execute the assignment process where the standard transit assignment model implemented in this software is based on the concept of optimal strategies which minimize transfer, waiting and in-vehicle time [18]. The most general formulation of this model is described in Spiess [19], where the cost of a strategy is the sum of link travel times, $c_{a}$, weighted by the probability of traveling on link $a$, and the waiting time at nodes $i$ is weighted by the probability of traveling through node $i$. The assigning of the trips from all origins to destination $r$, according to the optimal strategy, corresponds to solving the following linear optimization problem:

$$
\operatorname{Min} \Sigma_{a \in A} c_{\alpha} v_{\alpha}+\Sigma_{i \in I} \omega_{i}
$$

Subject to

$$
\Sigma_{\alpha \in A_{i}}+v_{\alpha}-\Sigma_{a \in A_{i}^{i}}-v_{\alpha}=g_{i} i \in I_{x}
$$

\begin{tabular}{|l|r|l|}
\hline$v_{\alpha} \leq f_{\alpha} \omega_{i}$ & $a \in A_{i}^{+}$, & $i \in I_{x}$ \\
\hline$v_{\alpha}>0$ & $a \in A$ & \\
\hline
\end{tabular}

Variables $\omega_{i}$ as in formula (2) represent the total waiting time (in person minutes) at node $i$. Further and detail explanation on the mathematical derivation of the above objective function can be found in Spiess [19]. Using the generalized formulation as in equation (1), any transit network $T$ can be represented, and the mechanics that are involved in constructing the links and the nodes of the generalized network depend very much on the particularities of the transit network and the degree of aggregation considered. The fundamental concept of this strategy is based on the assumption that a passenger arrived at a station select an optimum route from a group of route randomly to reach his or her destination and board the the first vehicle arrived. This mechanism is done repetitively until reaching the final destination.

Prior to conducting a simulation, future O-D Matrix is developed by applying the gravity model and the forecasted trip generation. Then, based on several assumptions and scenarios set in this research, a simulation to ridership is conducted through the validated transit assignment procedure. Once the simulation is done, the estimated total boarding passenger and passenger profile (flow) at peak hour for each BST service line is then analyzed. Referring to the passenger profile (flow) resulted from the simulation, the maximum flow is identified and the average flow is calculated for each service line. Finally, based on these two values the design capacity for each service line is determined. Diagramatically, the research framework is summarized in Figure 1. 


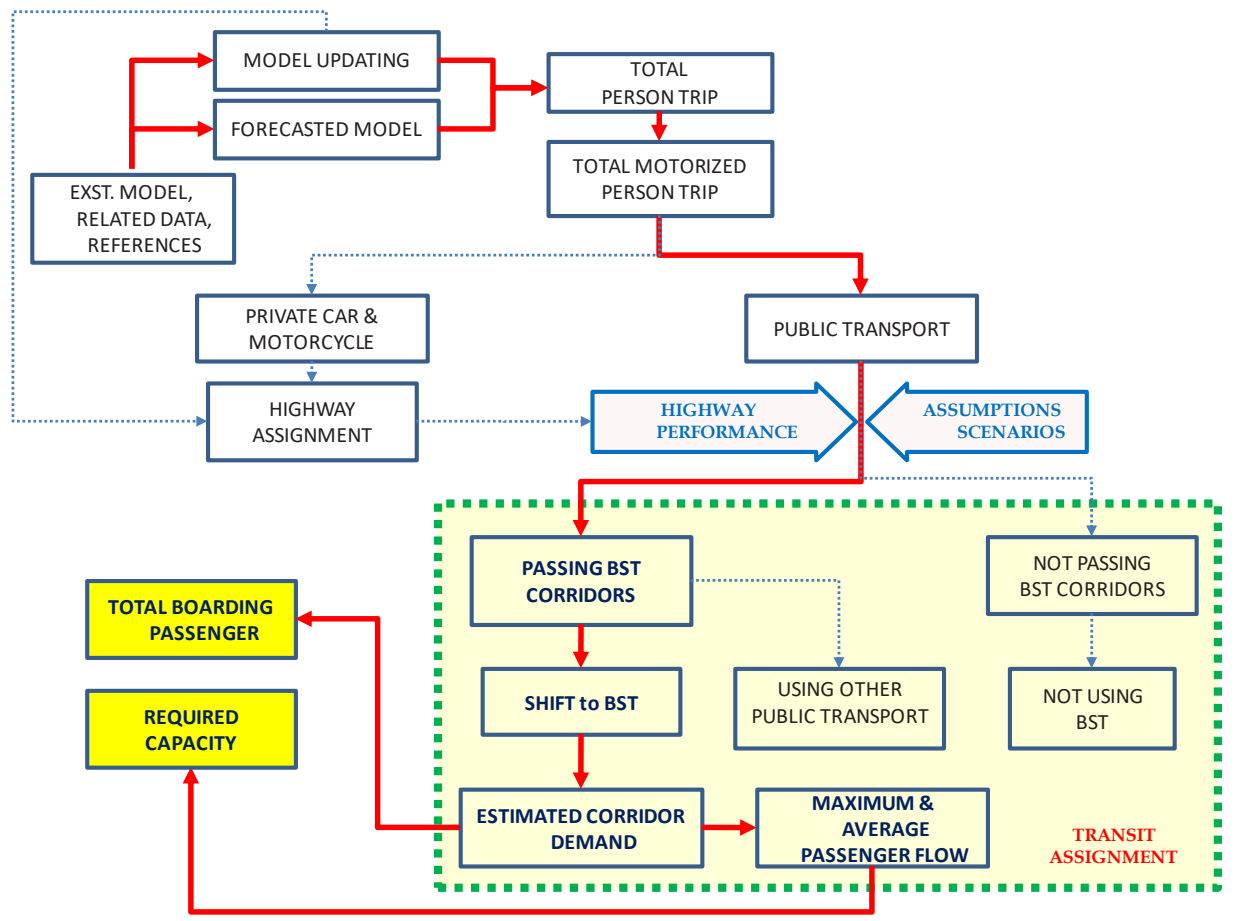

Fig. 1. Research framework

\section{Assumptions and scenarios}

To obtain the ridership through model simulation, some basic assumptions and scenarios related with trip generation, public transport share, and operational parameter of the system need to be established first. Referring to previous work [1], the population growth rate for Jabodetabek area from 1971 to 2005 is about of 4,7\% per annum and that for DKI Jakarta is around 2,0\% per annum. In 2020, the growth rate prediction is about $1,32 \%$ and $0,49 \%$ per annum for Bodetabek and Jakarta respectively. While in 2030, the prediction is about $1,03 \%$ and $0,19 \%$ per annum for Bodetabek and Jakarta respectively. Based on these population growth rate prediction, the trip growth for each district (kelurahan) in Jabodetabek area is derived and the trip growth for each district (kelurahan) in Jabodetabek area ranges from $0.77 \%$ to $1.99 \%$ for each local city in Jabodetabek with avarege of $1.38 \%$ in 2020 and $0.95 \%$ in 2030 [17].

The current public transport share adopted for this research is taken from the home interview survey conducted in the previous work [11], which is $24 \%$ from the total motorised person trip in Jabodetabek area. While, all each public transport mode parameter, the proposed BST implementation staging and tariff rate are adapted from the previous work [1]. In supply side, as in RITJ [1], the proposed BST is divided into two different services namely express and reguler BST. Since the reguler BST service route has not been defined yet, this research will only consider the express BST routes for the analysis. The supply-demand scenario developed in this research is summarized in Table 1. 
Table 1. Supply and demand scenario

\begin{tabular}{|c|c|}
\hline Scenario & Description \\
\hline SD-22 & $\begin{array}{l}\text { Consider transport network (S) plan and potential demand (D) for the year of } \\
\text { 2020, Fare integration applies for the same mode technology only, except for the } \\
\text { existing bus systema , while for physical integration }{ }^{\mathrm{b}} \text { applies for all type of public } \\
\text { transport mode, excepts for the existing bus system. }\end{array}$ \\
\hline SD-23 & Similar with the SD-22, but consider potential demand (D) for the year of 2030 \\
\hline SD-33 & $\begin{array}{l}\text { Similar with SD-22, but consider transport network (S) plan and potential demand } \\
\text { (D) for the year of } 2030\end{array}$ \\
\hline
\end{tabular}

\section{Simulation and analysis}

Referring to model simulation on Jabodetabek road network, the predicted network performance is shown in Table 2. The road network performance shown in Table 2 consists of the average link speed and the average travel speed, where the former is purely based on each link speed either towards to the city center or vice versa, and the later is calculated by taking into account the traffic flow at the respected link (i.e. weighing the speed with the traffic flow). It is important to explain this a bit further because the link speed does not reflect the congestion perceived by the user in the real situation, but the average travel speed. Therefore link speed is usually higher than the travel speed as shown in Table 2.

Table 2. Highway network performance ( $\mathrm{km} / \mathrm{hour})$

\begin{tabular}{|l|r|r|r|r|}
\hline & \multicolumn{2}{|c|}{ Averg. Link Speed } & \multicolumn{2}{c|}{ Averg. Travel Speed } \\
\hline \multicolumn{1}{|c|}{ Region } & \multicolumn{1}{c|}{2020} & \multicolumn{1}{c|}{2030} & \multicolumn{1}{c|}{2020} & \multicolumn{1}{c|}{2030} \\
\hline Jakarta & 23.4 & 19.3 & 13.6 & 10.6 \\
\hline Tangerang City & 20.0 & 14.4 & 12.7 & 9.4 \\
\hline Tangerang District & 19.4 & 15.7 & 11.2 & 8.8 \\
\hline South Tangerang City & 26.1 & 21.2 & 15.4 & 12.6 \\
\hline Depok City & 20.8 & 16.3 & 11.5 & 8.5 \\
\hline Bekasi City & 20.8 & 18.7 & 11.4 & 10.5 \\
\hline Bekasi District & 22.6 & 21.2 & 13.4 & 12.0 \\
\hline Bogor City & 27.7 & 26.5 & 12.5 & 13.8 \\
\hline Bogor District & 27.1 & 24.4 & 15.7 & 13.5 \\
\hline Average & 23.3 & 19.8 & 13.5 & 10.9 \\
\hline
\end{tabular}

By using the predicted road link speed as a basis for mix-traffic roadbase public transport design speed, a simulation to the proposed Mass Transit System in RITJ (i.e. Rail and Roadbase Mass Transit) is then conducted. From the simulation, the potential demand for the proposed Express Jabodetabek BST represented in peak hour total boarding passenger is shown in Table 3.

Besides the total boarding passenger, the simulation result also comes up with passenger profile demand (i.e. sectional passenger flow/volume) along the service line. Based on this profile demand, the maximum passenger flow (peak hour passenger per direction/phpd) on each service line are determined. Ideally the design capacity for a designated line is based on the maximum flow, hence it will guarrante that all passenger can be accommodated. Yet, by taking the maximum flow as the design capacity, there will be a situation where 
most of section in the line will experience quite low load factor. This is considered not good from the operational cost point of view, because financially it is not efficient. In order to avoid and compromise this undesirable situation, it is advisable to set an envelope as the design capacity which will form a lower and upper boundary. Therefore an average flow is calculated and set as the lower boundary of the design capacity, while the maximum flow is set as the upper boundary. Having calculated the average flow for each service line, the capacity need to be provided for the proposed BST is shown in Table 4.

Table 3. Jabodetabek Express BST potential demand (pax/hr)

\begin{tabular}{|l|l|r|r|r|c|c|}
\hline \multirow{2}{*}{ Line_ID } & \multirow{2}{*}{ Service Line O-D } & \multicolumn{2}{|c|}{ Supply-Demand Scenario } & \multicolumn{2}{c|}{ Change (\%) } \\
\cline { 3 - 7 } & & SD-22 & SD-23 & SD-33 & $\square$ SD $_{(23-22)}$ & $\square \mathrm{SD}_{(33-23)}$ \\
\hline BPX1 & Bekasi-Senen & 32,114 & 33,999 & 14,074 & 6 & -59 \\
\hline BPX2 & Depok-BlokM & 13,692 & 14,540 & 12,389 & 6 & -15 \\
\hline BPX3 & Bogor-Senen & 14,512 & 15,184 & 14,493 & 5 & -5 \\
\hline BPX4 & Poris-BlokM & 16,941 & 18,401 & 7,707 & 9 & -58 \\
\hline BPX5 & Cikarang-BlokM & 47,811 & 51,420 & 19,533 & 8 & -62 \\
\hline BPX6 & Cibinong_Grogol & 15,476 & 16,553 & 6,094 & 7 & -63 \\
\hline BPX7 & TnAbang-Bekasi & 25,700 & 27,407 & 13,499 & 7 & -51 \\
\hline BPX8 & Depok-Senen & 10,561 & 10,903 & 11,281 & 3 & 3 \\
\hline BPX9 & Depok-TNAbang & 10,771 & 11,260 & 10,730 & 5 & -5 \\
\hline BPX10 & Poris-Senen & 4,004 & 4,168 & 1,570 & 4 & -62 \\
\hline BPX11 & Poris-TnAbang & 3,137 & 3,301 & 1,187 & 5 & -64 \\
\hline BPX12 & PdCabe-Senen & 11,985 & 12,926 & 8,930 & 8 & -31 \\
\hline BPX13 & PdCabe-TnAbang & 11,385 & 12,327 & 9,049 & 8 & -27 \\
\hline BPX14 & PsAnyar-Senen & 4,206 & 4,394 & 1,624 & 4 & -63 \\
\hline BPX15 & BSD City-Senen & 6,633 & 7,077 & 3,110 & 7 & -56 \\
\hline BPX16 & BSD-TnAbang & 6,138 & 6,575 & 3,592 & 7 & -45 \\
\hline BPX17 & Ciledug-TnAbang & 7,640 & 8,101 & 3,341 & 6 & -59 \\
\hline BPX18 & Depok-Manggarai & 6,489 & 6,764 & 7,072 & 4 & 5 \\
\hline BPX19 & HrIndah-Cikarang & 4,510 & 4,879 & 1,922 & 8 & -61 \\
\hline BPX20 & Kalideres-Poris Ext. & 462 & 509 & 59 & 10 & -88 \\
\hline
\end{tabular}

Referring to Table 3, in 2020 (i.e. scenario SD-22), BST potential demand has a very wide range from 462 passenger/hour to as many as 47,000 passenger/hour. When all assumptions in scenario SD-22 hold, , there are three BST service lines, namely BPX-1, BPX-5 ans BPX-7, have a very high (more than 25,000 passenger/hour) demand and one service line, BPX-20, has very low demand.

When the 2020 network is assigned with 2030 demand, indicated with scenario SD-23, demand on all BST lines are slightly increase by $3 \%$ to $10 \%$. Yet, in 2030 , this situation is totally different when new services like Jabodetabek Regular BST network, East-West MRT corridor and LRT network [1] are operated. Simulation results yield that demand on $65 \%$ of BST service lines are significantly decreased which count for more than $40 \%$ compared with those of scenario SD-22. Having observed all BST service lines highly 
affected by these new services (i.e. service lines marked with bold letter and shading) in Table 3 and taking a closer look at their ittenerary in Figure A-1 as in the Appendix, seems that these affected lines mostly (11 of 13 lines) serve East-West direction trip. Therefore, to identify which new service gives most impact to the BST potential demand, a further analysis on demand shifting pattern is carried out by comparing number of passenger of each mass transit line for different supply-demand scenario as in Table 1. From the simulation result, the demand shifting pattern is depicted in Figure 5 with passenger flow map.

Table 4. Transjabodetabek Express BST estimated capacity

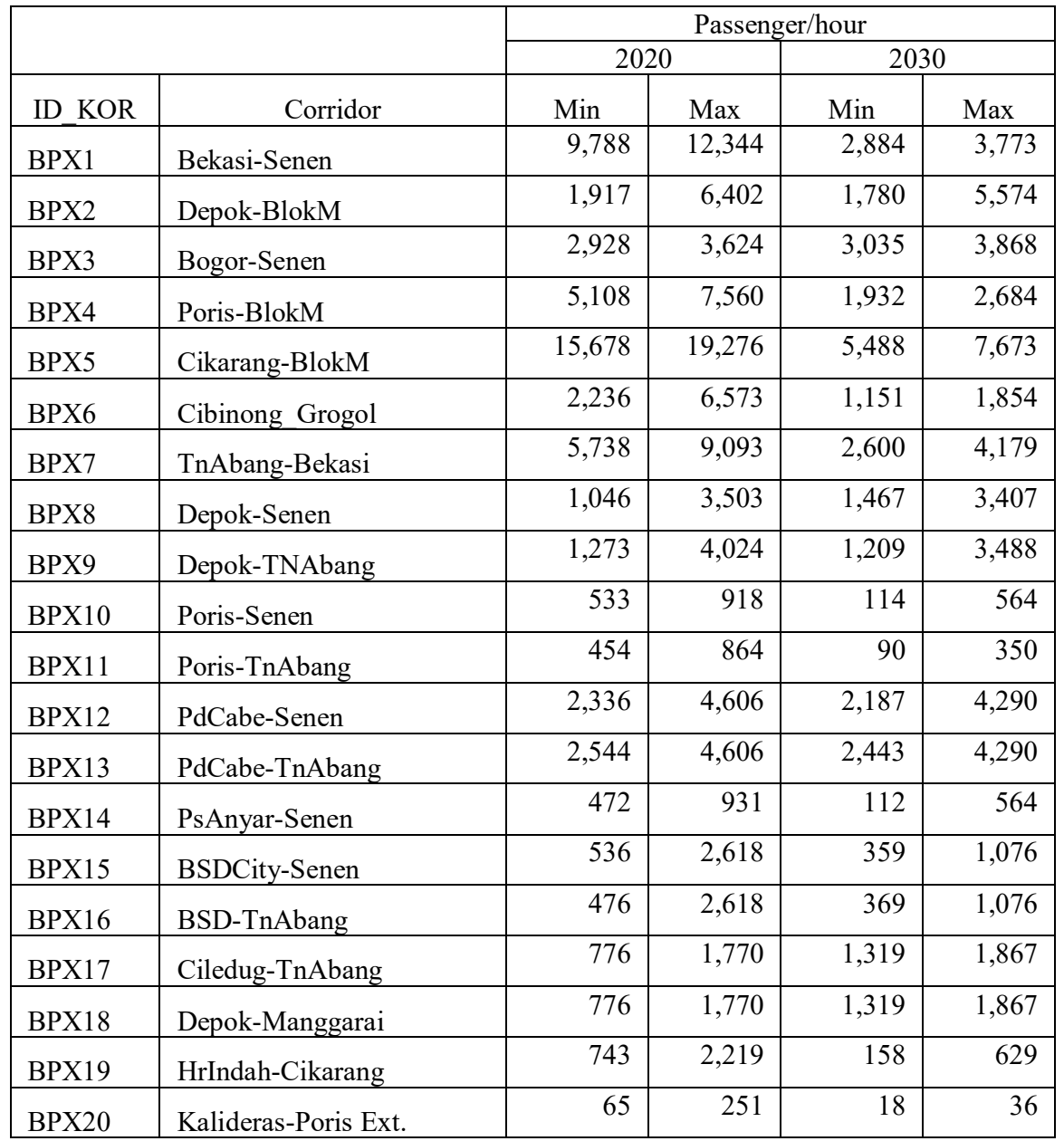

This shifting pattern is distinguished with two different colour, where lines experiencing reduced demand are marked with red colour, and lines having additional demand are marked with green colour. The line thickness indicates the amount of shifted passenger to or from other service line. Referring to Figure 5 and Figure A-1 to Figure A-3 in the Appendix, it is shown that all new mass transit services take some of the BST line's demand and the E-W MRT corridor consumes the biggest share of this shifted demand as indicated by thickness of the flow map. So, this situation could explain why all BST lines which serves East-West movement direction are the most suffered services in term of 
passenger or demand reduction. As a consequence, similar phenomenon also occurs in the estimated capacity for several lines marked with bold letter and shading indicated in Table 4. In order to make sure the consistency of BST lines having suffered from shifted demand resulted in the total boarding and the capacity estimation, a simple comparison between marked lines in Table 3 and those of in Table 4 is made. This comparison shows a conformity as shown in Table A-1 in the Appendix, where all nine BST lines that serve East-West direction movement are marked as the most suffered lines due to the operation of E-W MRT corridors.

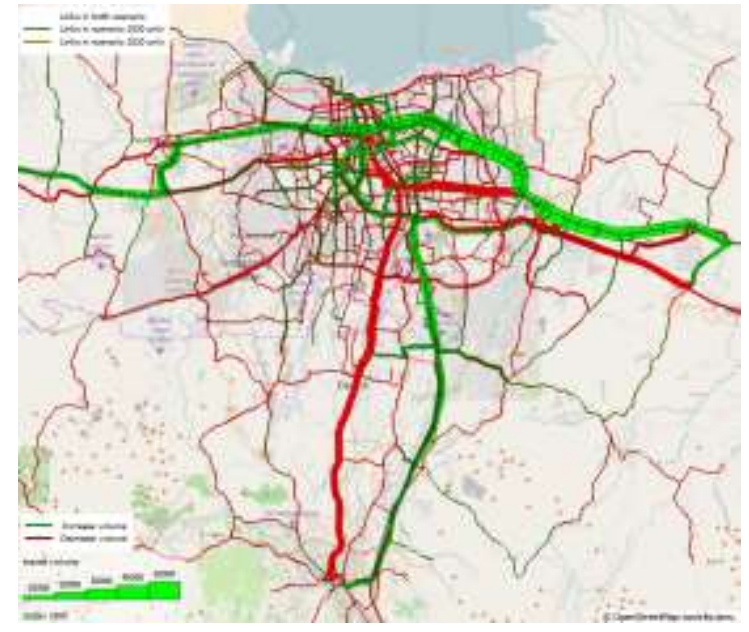

Fig. 5. Shifted demand between mass transit

\section{Conclusion}

A demand forecast analysis on the BST network of Jabodetabek Transport Master Plan (RITJ) is conducted and yields to the estimated ridership and required capacity for each service line proposed in the plan. Since most of mass transit proposed in RITJ is heavily on the roadbase system, as a consequent, highway average network speed is predicted and then this predicted speed is used as the roadbase mass transit design speed at the respected link. The analysis shows that in 2020, the BST lines have a very wide range of potential demand which range from 462 passenger/hour to as many as 47,000 passenger/hour. It is also indentified that three service lines have a very high demand, and one line has very low demand. Further analysis in 2030 as in scenario SD-33, comes up with totally different BST demand figures where almost all lines which serve East-West direction experience a very substantial demand drop which account for more than $40 \%$ than those of in scenario SD-23. These situation also occurs for the estimated capacity of these affected BST service lines. An additional analysis is then conducted to identify which line service causes this shifted demand, and from the simulation result, appears that E-W MRT corridor absorps the most E-W BST service lines's potential demand.

\section{References}

1. IUTRI, Capacity And Demand Analysis Of Jabodetabek Mass Transit Network, Final Report, JICA(2016). 
2. Vuchic V. R. Bus Semirapid Transit Mode Development and Evaluation, Journal of Public Transportation, Volume 5, Nomor 2 (2002).

3. TRB, Transit capacity and Quality of Service Manual (TCQSM), TCRP Report 100, Transportation Research Board, Washington D.C (2003).

4. ITDP, Bus Rapid Transit Planning Guide, Institute for Transport Development \& Policy, New York (2007).

5. Deen, T.B. and Pratt, R.H. Evaluating Rapid Transit, in Public Transportation edt. Gray, G.G and Hoel, L.A., Prentice Hall, Inc., Englewood Cliffs New Jersey, USA, pp. 293 - 331 (1992).

6. Vuchic V. R. Urban Transit; Operations, Planning, and Economics, Wiley \& Sons Inc., Hoboken, New Jersey, USA (2005).

7. Wright, L. Bus Rapid Transit, Deutsche Gesellschaft für Technische Zusammenarbeit (GTZ) GmbH (2004).

8. Alvinsyah dan Hadian E. Analisis Dampak Aktifitas Kawasan Reklamasi Pantura terhadap Kinerja Jaringan Jalan di DKI Jakarta, Jurnal MTI Vol. 1 No. 1, hal. 43-58 (2016).

9. Kemenhub, Survey Wawancara Rumah Tangga di Kota Bekasi, Depok dan Bogor, Laporan Akhir, Badan Penelitian dan Pengembangan Kementerian Perhubungan (2014).

10. JICA, Study on an Integrated Transport Master Plan for Jabodetabek Area, Final Report (2004).

11. JICA, Study On Jabodetabek Urban Transportation Implementation Plan (Review On Sitramp-2004), $2^{\text {nd }}$ Draft Final Report (2011).

12. JICA, A Study on Jabodetabek Public Transport Implementation Strategy (JapTraPIS), Final Report (2012).

13. BSTP, Studi Penyusunan Master Plan Pola Transportasi Makro (PTM) Jabodetabek Tahap I, Direktorat Jendral Perhubungan Darat, Final Report (2009).

14. BSTP, Studi Pedoman Perencanaan Trayek Pengumpan (Feeder) untuk Angkutan Massal Berbasis Jalan, Direktorat Jendral Perhubungan Darat, Final Report (2010).

15. CTS, Pola Transportasi Makro Jakarta, Final Report, Dishub DKI - CTS UI (2004).

16. KOICA, Master Plan for Jabodetabek Railway, PMC Service for Master Plan and Feasibility Study for Jabodetabek Railway in Indonesia, Final Report (2012).

17. Hadian and Alvinsyah, Impact On Ridership Of New Railbase Transit Due To The Operation Of Extensive Bus Semi Transit Network (Case Study: Greater Jakarta (Jabodetabek) Public Transport Network), Proceeding of $15^{\text {th }}$ International Conference on Quality in Research (2017).

18. INRO, User Manual, EMME Suite, Montreal (2015).

19. Spiess H., and Florian, M., , Optimal Strategies: A New Assignment Model for Transit Networks, Transportation Research Part B: Methodological, Volume 23B No. 2, pp 83-102 (1989).

20. Kemenhub, Survey Wawancara Rumah Tangga di Kota Tangerang dan Tangerang Selatan, Laporan Akhir, Badan Penelitian dan Pengembangan Kementerian Perhubungan (2013). 


\section{Appendix}

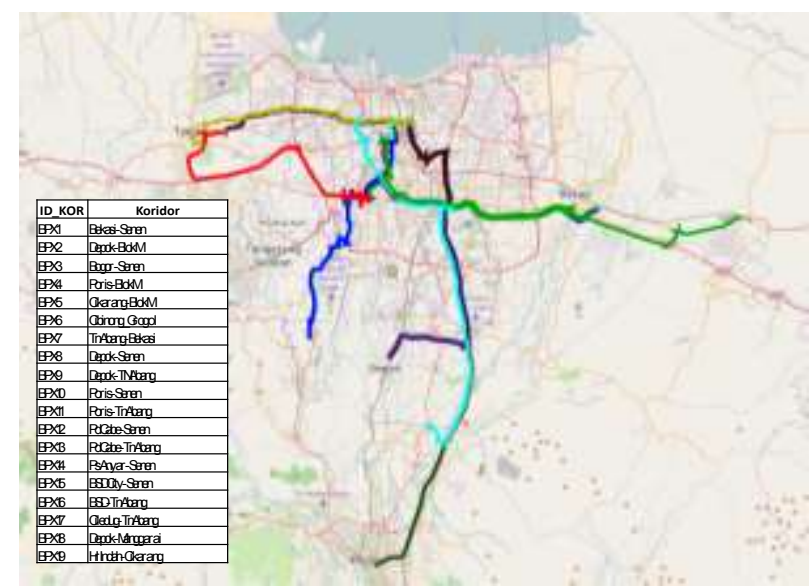

Fig. A-1. HCB network in 2020

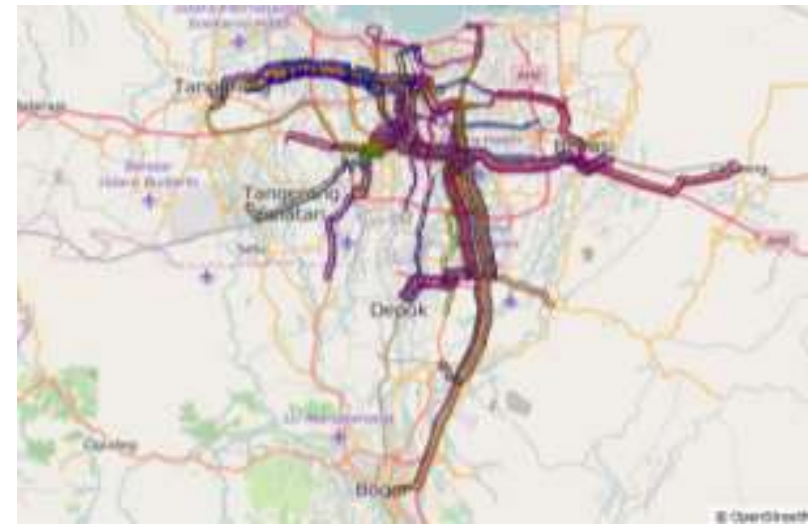

Fig. A-2. HCB network in 2030

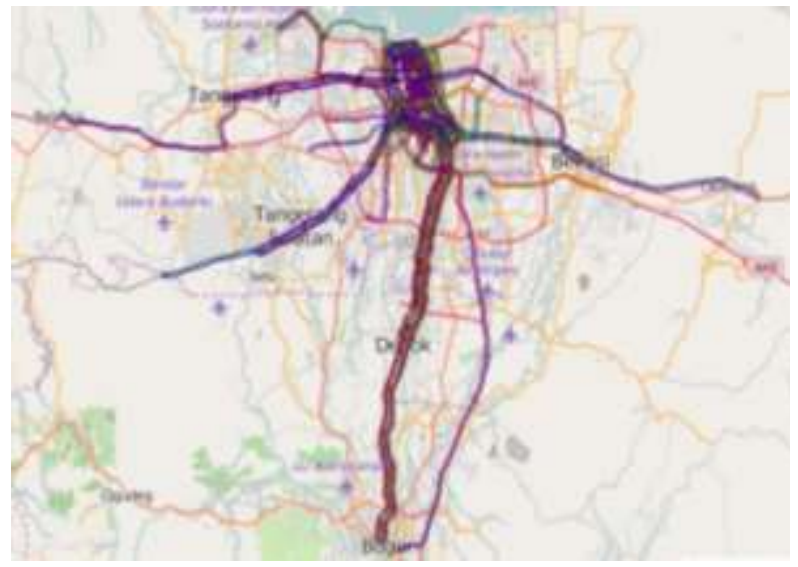

Fig. A-3. Rail network in 2030 
Table A-1. List of affected Jabodetabek BST line

\begin{tabular}{|l|l|l|}
\hline Line_ID & \multicolumn{1}{|c|}{ Total Boarding } & Capacity Provision \\
\hline BPX1 & Bekasi-Senen & Bekasi-Senen \\
\hline BPX4 & Poris-BlokM & Poris-BlokM \\
\hline BPX5 & Cikarang-BlokM & Cikarang-BlokM \\
\hline BPX6 & Cibinong_Grogol & Cibinong_Grogol \\
\hline BPX7 & TnAbang-Bekasi & TnAbang-Bekasi \\
\hline BPX10 & Poris-Senen & Poris-Senen \\
\hline BPX11 & Poris-TnAbang & Poris-TnAbang \\
\hline BPX14 & PsAnyar-Senen & PsAnyar-Senen \\
\hline BPX16 & BSD-TnAbang & BSD-TnAbang \\
\hline BPX17 & Ciledug-TnAbang & Ciledug-TnAbang \\
\hline BPX19 & HrIndah-Cikarang & HrIndah-Cikarang \\
\hline BPX20 & Kalideres-Poris Ext. & Kalideres-Poris Ext. \\
\hline
\end{tabular}

